\title{
Template-Directed Synthesis of Mechanically Interlocked Molecular Bundles Using Dynamic Covalent Chemistry
}

2006

Vol. 8, No. 18 3899-3902

\section{Brian H. Northrop, Fabio Aricó, Nick Tangchiavang, Jovica D. Badjić, and J. Fraser Stoddart*}

Department of Chemistry and Biochemistry and the California NanoSystems Institute, University of California-Los Angeles, 405 Hilgard Avenue, Los Angeles, California 90095

stoddart@chem.ucla.edu

Received May 23, 2006

\section{ABSTRACT}
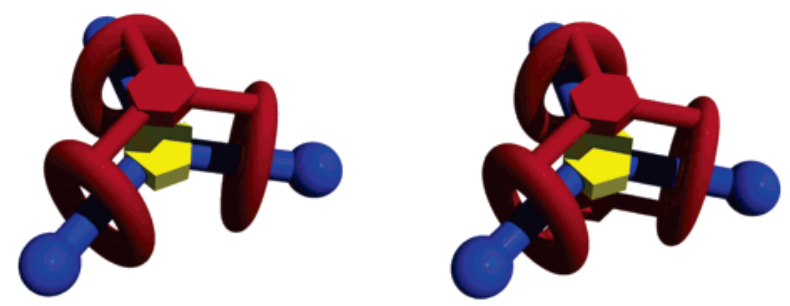

Mixing the dipyrido[24]crown-8 derivatives carrying one or two formyl group(s) on the 4 position(s) of their pyridine ring(s) with a 3-fold symmetrical trisammonium ion template in a 3:1 ratio in $\mathrm{CD}_{3} \mathrm{NO}_{2}$ results in the formation of thermodynamically stable [4]pseudorotaxanes which, upon addition of a 1,3,5-trisaminobenzene cap, form mechanically interlocked molecular bundles with one and two caps, respectively, by virtue of dynamic imine bond formation.

Beginning with the first chemical synthesis of a catenane by Wasserman ${ }^{1}$ in 1960 , molecular compounds that exhibit exotic topologies and/or mechanical bonds have been targeted by synthetic chemists. Mechanically interlocked and knotted compounds, such as catenanes, ${ }^{2}$ rotaxanes, ${ }^{3}$ trefoil knots, ${ }^{4}$ and Borromean rings ${ }^{5}$ synthesized usually by templatedirected $^{6}$ protocols depending on molecular recognition ${ }^{7}$ and self-assembly ${ }^{8}$ processes, represent challenging synthetic goals that have nonetheless been realized. While much progress has been made in developing synthetic strategies to make such compounds, molecules exist ${ }^{9}$ beyond this first

(1) (a) Wasserman, E. J. Am. Chem. Soc. 1960, 82, 4433-4434. (b) Frisch, H.; Wasserman, E. J. Am. Chem. Soc. 1961, 83, 3789-3795.

(2) Catenanes are molecules comprised of two (or more) ring-shaped components that are interlocked like the links in a chain. See: (a) Schill, G. Catenanes, Rotaxanes and Knots; Academic Press: New York, 1971. (b) Molecular Catenanes, Rotaxanes and Knots; Sauvage, J.-P., DietrichBuchecker, C., Eds.; Wiley-VCH: Weinheim, 1999. crop of compounds that need to be accessed by chemical synthesis.

(3) Rotaxanes are molecules comprised of ring-shaped component(s) and dumbbell-shaped component(s) that are mechanically interlocked. For recent examples, see: (a) Stainer, C. A.; Alderman, S. J.; Claridge, T. D. W.; Anderson, H. L. Angew. Chem., Int. Ed. 2002, 41, 1769-1772. (b) Andersson, M.; Linke, M.; Chambron, J.-C.; Davidson, J.; Heitz, V.; Hammarström, L.; Sauvage, J.-P. J. Am. Chem. Soc. 2002, 124, 43474362. (c) Asakawa, M.; Brancato, G.; Fanti, M.; Leigh, D. A.; Shimizu, T.; Slawin, A. M. Z.; Wong, J. K. Y.; Zerbetto, F.; Zhang, S. J. Am. Chem. Soc. 2002, 124, 2939-2950. (d) Nikitin, K.; Long, B.; Fitzmaurice, D. Chem. Commun. 2003, 282-283. (e) Iijima, T.; Vignon, S. A.; Tseng, H.R.; Jarrosson, T.; Sanders, J. K. M.; Marchioni, F.; Venturi, M.; Apostoli, E.; Balzani, V.; Stoddart, J. F. Chem.-Eur. J. 2004, 10, 6375-6392.

(4) For examples of synthetic trefoil knots, see: (a) Dietrich-Buchecker, C. O.; Sauvage, J.-P. Angew. Chem., Int. Ed. Engl. 1989, 28, 189-192. (b) Carina, R. F.; Dietrich-Buchecker, C. O.; Sauvage, J.-P. J. Am. Chem. Soc. 1996, 118, 9110-9116. (c) Ashton, P. R.; Matthews, O. A.; Menzer, S.; Raymo, F. M.; Spencer, N.; Stoddart, J. F.; Williams, D. J. Liebigs Ann. Chem. 1997, 2485-2494. (d) Hunter, C. A.; Mayers, P. C. Nature 2001, 411, 763. (e) Lukin, O.; Kubota, T.; Okamoto, Y.; Kaufmann, A.; Vögtle, F. Chem.-Eur. J. 2004, 10, 2804-2810 
Dynamic covalent chemistry ${ }^{10}$ (DCC) has emerged as an efficient and versatile strategy for the synthesis of complex molecular structures. Whereas early examples of supramolecular assistance to covalent synthesis ${ }^{11}$ relied heavily on kinetically controlled reactions for postassembly covalent modification, DCC takes advantage of the reversible nature of acetal, ${ }^{12}$ disulfide, ${ }^{13}$ ester, ${ }^{14}$ and imine ${ }^{15}$ bond formation, as well as carbon-carbon bond formation during methasis ${ }^{16}$ and metal-ligand coordination, ${ }^{17}$ to allow the formation of the new covalent bonds to be thermodynamically controlled. The reversible formation of covalent bonds provides a means of proofreading and editing intermediate structures to achieve, with time, the most thermodynamically stable product. When coupled with templation, DCC has been shown

(5) (a) Chichak, K. S.; Cantrill, S. J.; Pease, A. R.; Chiu, S.-H.; Cave, G. W. V.; Atwood, J. L.; Stoddart, J. F. Science 2004, 304, 1308-1312. (b) Siegel, J. S. Science 2004, 304, 1256-1258. (c) Schalley, C. A. Angew. Chem., Int. Ed. 2004, 43, 4399-4401. (d) Chichak, K. S.; Peters, A. J.; Cantrill, S. J.; Stoddart, J. F. J. Org. Chem. 2005, 70, 7956-7962.

(6) (a) Anderson, S.; Sanders, J. K. M. Acc. Chem. Res. 1993, 26, 469475. (b) Hoss, R.; Vögtle, F. Angew. Chem., Int. Ed. Engl. 1994, 33, 374384. (c) Schneider, J. P.; Kelly, J. W. Chem. Rev. 1995, 95, 2169-2187. (d) Raymo, F. M.; Stoddart, J. F. Pure Appl. Chem. 1996, 68, 313-322. (e) Templated Organic Synthesis; Diederich, F., Stang, P. J., Eds.; WileyVCH: Weinheim, 1999. (f) Stoddart, J. F.; Tseng, H.-R. Proc. Natl. Acad. Sci. U.S.A. 2002, 99, 4797-4800. (g) Busch, D. H. Top. Curr. Chem. 2005, $249,1-65$.

(7) (a) Lehn, J.-M. Supramolecular Chemistry; VCH: Weinheim, 1995. (b) Lindoy, L. F.; Atkinson, I. M. Self-Assembly in Supramolecular Systems; Stoddart, J. F., Ed.; RSC: Cambridge, 2000. (c) Lehn, J.-M. Science 2002, 295, 2400-2403. (d) Reinhoudt, D. N.; Crego-Calama, M. Science 2002, 295, 2403-2407. (e) Meyer, E. A.; Castellano, R. K.; Diederich, F. Angew. Chem., Int. Ed. 2003, 42, 1210-1250.

(8) (a) Lindsey, J. S. New J. Chem. 1991, 15, 153-180. (b) Philp, D.; Stoddart, J. F. Angew. Chem., Int. Ed. 1996, 35, 1154-1195. (c) Fujita, M. Acc. Chem. Res. 1999, 32, 53-61. (d) Rebek, J., Jr. Acc. Chem. Res. 1999, 32, 278-286. (e) Bong, D. T.; Clark, T. D.; Granja, J. R.; Ghadiri, M. R. Angew. Chem., Int. Ed. 2001, 40, 988-1011. (f) Seidel, S. R.; Stang, P. J. Acc. Chem. Res. 2002, 35, 972-983. (g) Yaghi, O. M.; O'Keeffe, M.; Ockwig, N. W.; Chae, H. K.; Eddaoudi, M.; Kim, J. Nature 2003, 423, 705-714.

(9) For a preliminary discussion of the mechanically interlocked molecules beyond catenanes and rotaxanes, see: Chang, T.; Heiss, A. M.; Cantrill, S. J.; Fyfe, M. C. T.; Pease, A. R.; Rowan, S. J.; Stoddart, J. F.; Williams, D. J. Org. Lett. 2000, 2, 2943-2946.

(10) Rowan, S. J.; Cantrill, S. J.; Cousins, G. R. L.; Sanders, J. K. M.; Stoddart, J. F. Angew. Chem., Int. Ed. 2002, 41, 898-952.

(11) For examples of the kinetic approach, see: (a) Fyfe, M. C. T.; Stoddart, J. F. Acc. Chem. Res. 1997, 30, 393-401. (b) Rowan, S. J.; Cantrill, S. J.; Stoddart, J. F. Org. Lett. 1999, 1, 129-132.

(12) (a) Fuchs, B.; Nelson, A.; Star, A.; Stoddart, J. F.; Vidal, S. Angew. Chem., Int. Ed. 2003, 42, 4220-4242. (b) Cacciapaglia, R.; Di Stefano, S.; Mandolini, L. J. Am. Chem. Soc. 2005, 127, 13666-13671.

(13) (a) Kolchinski, A. G.; Alcock, N. W.; Roesner, R. A.; Busch, D. H. Chem. Commun. 1998, 1437-1438. (b) Hioki, H.; Still, W. C. J. Org. Chem. 1998, 63, 904-905. (c) Otto, S.; Furlan, R. L. E.; Sanders, J. K. M. J. Am. Chem. Soc. 2000, 122, 12063-12064. (d) Ramström, O.; Lehn, J.M. ChemBioChem 2000, 1, 41-48. (e) Otto, S.; Furlan, R. L. E.; Sanders, J. K. M. Science 2002, 297, 590-593. (f) Brisig, B.; Sanders, J. K. M.; Otto, S. Angew. Chem., Int. Ed. 2003, 42, 1270-1273. (g) Horikoshi, R.; Mikuriya, M. Cryst. Growth Des. 2005, 5, 223-230.

(14) (a) Brady, P. A.; Sanders, J. K. M. J. Chem. Soc., Perkin Trans. 1 1997, 3237-3253. (b) Rowan, S. J.; Sanders, J. K. M. J. Org. Chem. 1998, 63, 1536-1546. (c) Kaiser, G.; Sanders, J. K. M. Chem. Commun. 2000, $1763-1764$

(15) (a) Layer, W. R. Chem. Rev. 1963, 63, 489-510. (b) Dayagi, S.; Degani, Y. In The Chemistry of the Carbon-Nitrogen Double Bond; Patai, S., Ed.; Interscience: New York, 1970; pp 64-83. (c) Huc, I.; Lehn, J.-M. Proc. Natl. Acad. Sci. U.S.A. 1997, 94, 2106-2110.

(16) (a) Kidd, T. J.; Leigh, D. A.; Wilson, A. J. J. Am. Chem. Soc. 1999, 121, 1599-1600. (b) Weck, M.; Mohr, B.; Sauvage, J.-P.; Grubbs, R. H. J. Org. Chem. 1999, 64, 5463-5471. (c) Kilbinger, A. F. M.; Cantrill, S. J.; Waltman, A. W.; Day, M. W.; Grubbs, R. H. Angew. Chem., Int. Ed. 2003, 42, 3281-3285. (d) Wang, L.; Myroslav, O. V.; Bogdan, A.; Bolte, M.; Böhmer, V. Science 2004, 304, 1312-1214. (e) Guidry, E. N.; Cantrill, S. J.; Stoddart, J. F.; Grubbs, R. H. Org. Lett. 2005, 7, 2129-2132. to provide a highly efficient route to mechanically interlocked molecules. Recent examples include a calix[4]arene-based [8]catenane, ${ }^{16 \mathrm{~d}}$ multiple rotaxanes,${ }^{18}$ interlocked dendrimers,${ }^{19}$ and molecular Borromean rings. ${ }^{5}$ In some cases, the dynamic covalent structures have been fixed ${ }^{5,18,19}$ through reduction of their imine bonds to kinetically stable amine ones. Here, we describe the use of DCC in the context of imine bond formation, along with computational modeling, in the template-directed synthesis of two mechanically interlocked molecular bundles from five and six components, respectively. The pool of structures from which these components have been drawn is shown in Figure 1, and the manner in

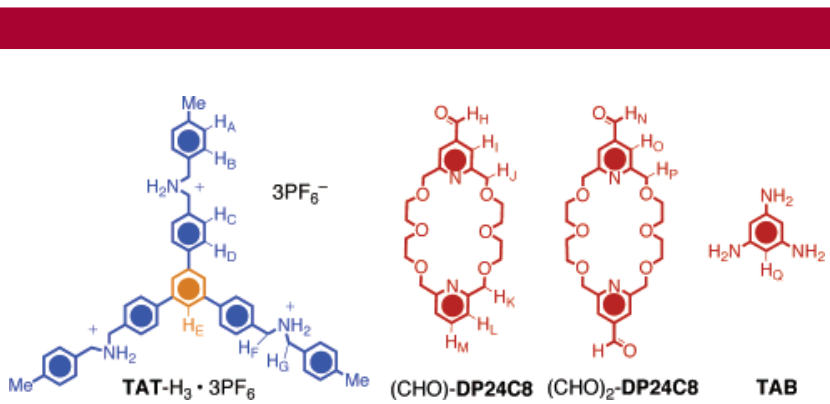

Figure 1. Structural formulas of the trisammonium ion template TAT $-\mathrm{H}_{3} \cdot 3 \mathrm{PF}_{6}$, the formyl derivatives $(\mathrm{CHO})-\mathbf{D P} 24 \mathbf{C 8}$ and $(\mathrm{CHO})_{2-}$ DP24C8 of dipyrido[24]crown-8 (DP24C8), and 1,3,5-trisaminobenzene (TAB). The proton descriptors employed in Figures 2 and 4 are defined on the four structural formulas.

which they have been employed in the two syntheses is outlined in Scheme 1. The supramolecular assistance to covalent synthesis ${ }^{11}$ is provided by hydrogen bonding between crown ether derivatives and secondary dialkylammonium ion centers, and the DCC uses imine bond formation to link together three individually derivatized crown ethers, carrying either one or two formyl groups, singly or doubly, with a trigonal capping reagent ${ }^{20}$ displaying the three matching amine functions.

Complexation occurs immediately upon addition of 3.0 equiv of (CHO)-DP24C8 to TAT- $\mathrm{H}_{3} \cdot 3 \mathrm{PF}_{6}$ in $\mathrm{CD}_{3} \mathrm{NO}_{2}$, as

(17) (a) Fujita, M.; Ibukuro, F.; Hagaira, H.; Ogura, K. Nature 1994 367, 720-725. (b) Baer, A. J.; Macartney, D. H. Inorg. Chem. 2000, 39, 1410-1417. (c) Chichak, K. S.; Walsh, M. C.; Branda, N. R. Chem. Commun. 2000, 847-848. (d) Gunter, M. J.; Bampos, N.; Johnstone, K. D.; Sanders, J. K. M. New J. Chem. 2001, 25, 166-173. (e) Stulz, E.; Ng, Y.-F.; Scott, S. M.; Sanders, J. K. M. Chem. Commun. 2002, 524-525. (f) Kubota, Y.; Sakamoto, S. S.; Yamaguchi, K.; Fujita, M. Proc. Natl. Acad. Sci. U.S.A. 2002, 99, 4854-4856. (g) Yoshizawa, M.; Nakagawa, J.; Kurnazawa, K.; Nagao, M.; Kawano, M.; Ozeki, T.; Fujita, M. Angew. Chem., Int. Ed. 2005, 44, 1810-1813.

(18) Aricó, F.; Chang, T.; Cantrill, S. J.; Khan, S. I.; Stoddart, J. F. Chem.-Eur. J. 2005, 11, 4655-4666.

(19) Leung, K. C.-F.; Aricó, F.; Cantrill, S. J.; Stoddart, J. F. J. Am. Chem. Soc. 2005, 127, 5808-5810.

(20) While the templating effect of $-\mathrm{CH}_{2} \mathrm{NH}_{2}{ }^{+} \mathrm{CH}_{2}-$ centers located in dumbbell components have been used to activate the formation of two imine bonds in macrocyclic polyethers to form rotaxanes in a process known as clipping (Glink, P. T.; Oliva, A. I.; Stoddart, J. F.; White, A. J. P.; Williams, D. J. Angew. Chem., Int. Ed. 2001, 40, 1870-1875. Horn, H.; Ihringer, I.; Glink, P. T.; Stoddart, J. F. Chem.-Eur. J. 2003, 9, 4040-4054.), the capping process described in this letter is more reminescent of forming rotaxanes under thermodynamic control by imine exchange (Rowan, S. J.; Stoddart, J. F. Org. Lett. 1999, 1, 1913-1916. Cantrill, S. J.; Rowan, S. J.; Stoddart, J. F. Org. Lett. 1999, 1, 1363-1366). 
Scheme 1. Addition of Either $(\mathrm{CHO})-\mathbf{D P} 24 \mathrm{C} 8$ or $(\mathrm{CHO})_{2}-\mathrm{DP} 24 \mathrm{C} 8$ to TAT $-\mathrm{H}_{3} \cdot 3 \mathrm{PF}_{6}$ in a $3: 1$ Ratio Leads to the Formation of the [4]Pseudorotaxanes MFPR- $\mathrm{H}_{3} \cdot 3 \mathrm{PF}_{6}$ and DFPR $-\mathrm{H}_{3} \cdot 3 \mathrm{PF}_{6}$, Respectively ${ }^{a}$

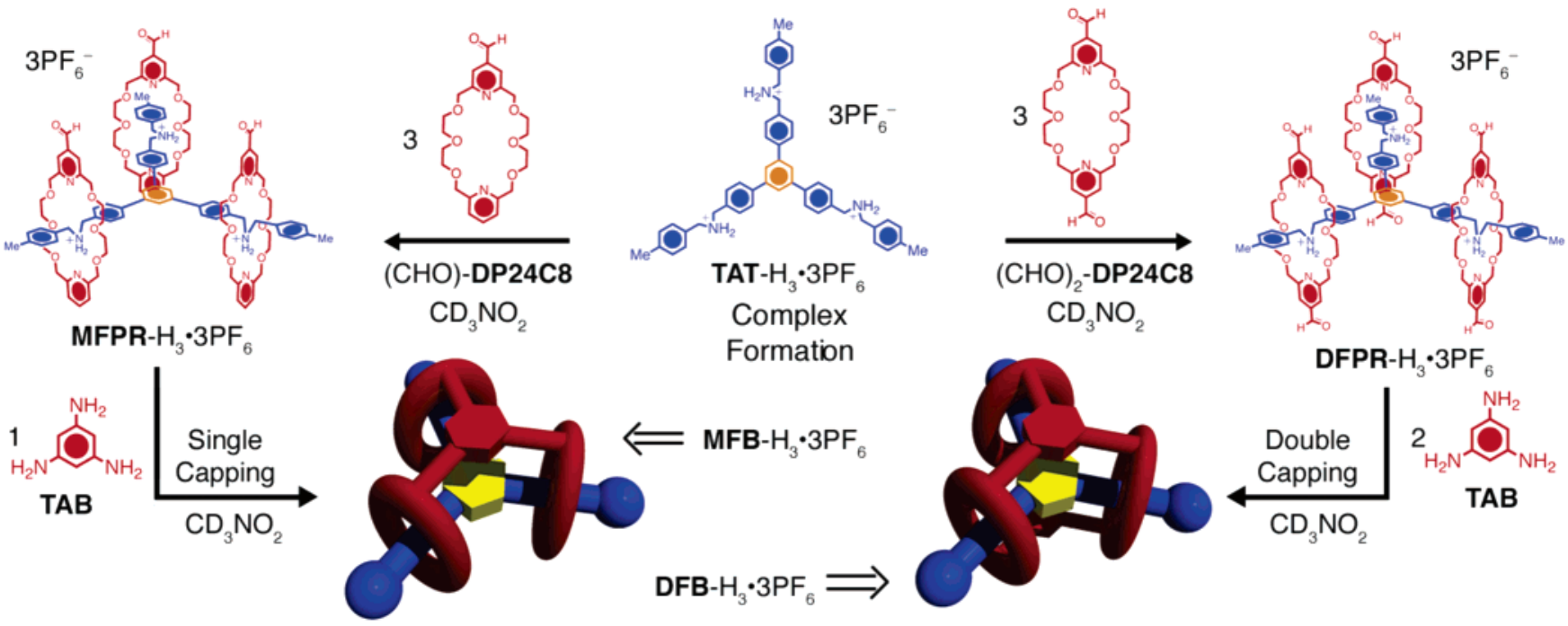

${ }^{a}$ Capping of these two complexes with 1.0 and 2.0 equiv, respectively, of TAB results in the formation of the mechanically interlocked molecular bundles $\mathbf{M F B}-\mathrm{H}_{3} \cdot 3 \mathrm{PF}_{6}$ and $\mathbf{D F B}-\mathrm{H}_{3} \cdot 3 \mathrm{PF}_{6}$, respectively.

indicated (Figure 2) by ${ }^{1} \mathrm{H}$ NMR spectroscopy. As is characteristic of the binding of $-\mathrm{CH}_{2} \mathrm{NH}_{2}{ }^{+} \mathrm{CH}_{2}-$ centers by crown ethers, the two pairs of benzylic methylene protons in TAT- $\mathrm{H}_{3}{ }^{3+}$ are shifted upfield from $\delta=4.5$ and $4.6 \mathrm{pm}$ to $\delta=3.9$ and $4.4 \mathrm{pm}$, respectively. Moreover, MFPR- $\mathrm{H}_{3}{ }^{3+}$ is a kinetically stable complex on the ${ }^{1} \mathrm{H}$ NMR timescale at $298 \mathrm{~K}$ because peaks can be identified for uncomplexed and
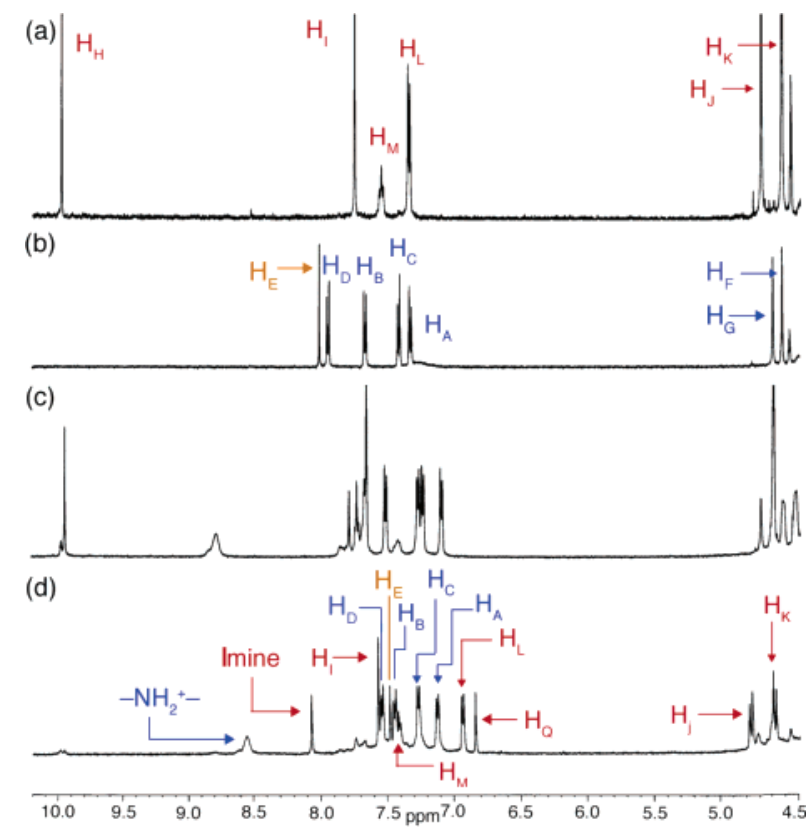

Figure 2. Partial ${ }^{1} \mathrm{H}$ NMR spectra $\left(\mathrm{CD}_{3} \mathrm{NO}_{2}, 13.8 \mathrm{mM}\right)$ of (a) (CHO)-DP24C8, (b) TAT- $\mathrm{H}_{3} \cdot 3 \mathrm{PF}_{6}$, (c) MFPR- $\mathrm{H}_{3} \cdot 3 \mathrm{PF}_{6}$, and (d) MFB- $\mathrm{H}_{3} \cdot 3 \mathrm{PF}_{6}$. For a definition of the proton $(\mathrm{H})$ descriptors, see Figure 1. partially complexed, as well as fully complexed, species. Integration of these peaks suggests that MFPR- $\mathrm{H}_{3}{ }^{3+}$ accounts for $>95 \%$ of the species present in solution. Isothermal titration microcalorimetry (ITC) indicates a "binding constant" per binding site of $11800 \mathrm{M}^{-1}\left(\Delta G^{\circ}=-5.5 \mathrm{kcal} /\right.$ mol) between TAT- $\mathrm{H}_{3}{ }^{3+}$ and (CHO)-DP24C8 in $\mathrm{MeNO}_{2}$. Computational force-field modeling (Figure $3 \mathrm{a}$ ) reveals that the three $\mathrm{NH}_{2}$ functions in $\mathbf{T A B}$ should be capable of forming imine bonds with the $\mathrm{CHO}$ groups in three complexed (CHO)-DP24C8 macrocycles. Indeed, although ${ }^{1} \mathrm{H}$ NMR spectroscopy reveals the formation of a number of products initially when 1.0 equiv of TAB is added to $\mathbf{M F P R}-\mathrm{H}_{3} \cdot 3 \mathrm{PF}_{6}$, after $2 \mathrm{~h}$ these kinetic intermediates converge ${ }^{21}$ to the most stable thermodynamic product $-\mathbf{M F B}-\mathrm{H}_{3} \cdot 3 \mathrm{PF}_{6}$ with 3 -fold $\left(C_{3 v}\right)$ symmetry-containing three imine bonds. This outcome $^{22}$ is supported (Figure $3 \mathrm{a}$ ) by high-resolution electrospray ionization (HR-ESI) mass spectrometric analysis: $\mathrm{m} / \mathrm{z}$ $=1131.52$ for $\left[\mathrm{M}-2 \mathrm{PF}_{6}\right]^{2+}$ compared with the calculated value of 1131.28.

Formation of DFPR- $\mathrm{H}_{3} \cdot 3 \mathrm{PF}_{6}$ was observed (Figure 4 ) by ${ }^{1} \mathrm{H}$ NMR spectroscopy to occur spontaneously upon mixing of $(\mathrm{CHO})_{2}$-DP24C8 and TAT- $\mathrm{H}_{3} \cdot 3 \mathrm{PF}_{6}$ in $\mathrm{CD}_{3} \mathrm{NO}_{2}$ in a $3: 1$ ratio. ITC measurements indicate a binding constant per binding site ${ }^{23}$ of $3520 \mathrm{M}^{-1}\left(\Delta G^{\circ}=-4.8 \mathrm{kcal} / \mathrm{mol}\right)$ between TAT- $\mathrm{H}_{3}{ }^{3+}$ and $(\mathrm{CHO})_{2}-\mathbf{D P 2 4 C 8}$ in $\mathrm{MeNO}_{2}$. Computational force-field modeling (Figure $3 \mathrm{~b}$ ) reveals that 2.0 equiv of TAB is capable of linking all six formyl functions of the

(21) Within 10 min of the addition, one witnesses a decrease in the intensity of the peak at $\delta=9.95 \mathrm{ppm}$ for formyl protons as the intensity of the singlet at $\delta=8.10 \mathrm{ppm}$ for imine protons increases simultaneously.

(22) All attempts to obtain X-ray quality single crystals of $\mathbf{M F B}-\mathrm{H}_{3}$. $3 \mathrm{PF}_{6}$ and $\mathbf{D F B}-\mathrm{H}_{3} \cdot 3 \mathrm{PF}_{6}$ or to reduce (e.g., with $\mathrm{BH}_{3}-\mathrm{THF}$ and $\mathrm{BH}_{3}$-lutidine) the three and six imine bonds, respectively, have been unsuccessful to date. Hence, the evidence for the formation of these two mechanically interlocked compounds rests primarily on ${ }^{1} \mathrm{H}$ NMR spectroscopy and mass spectrometry for the present. 

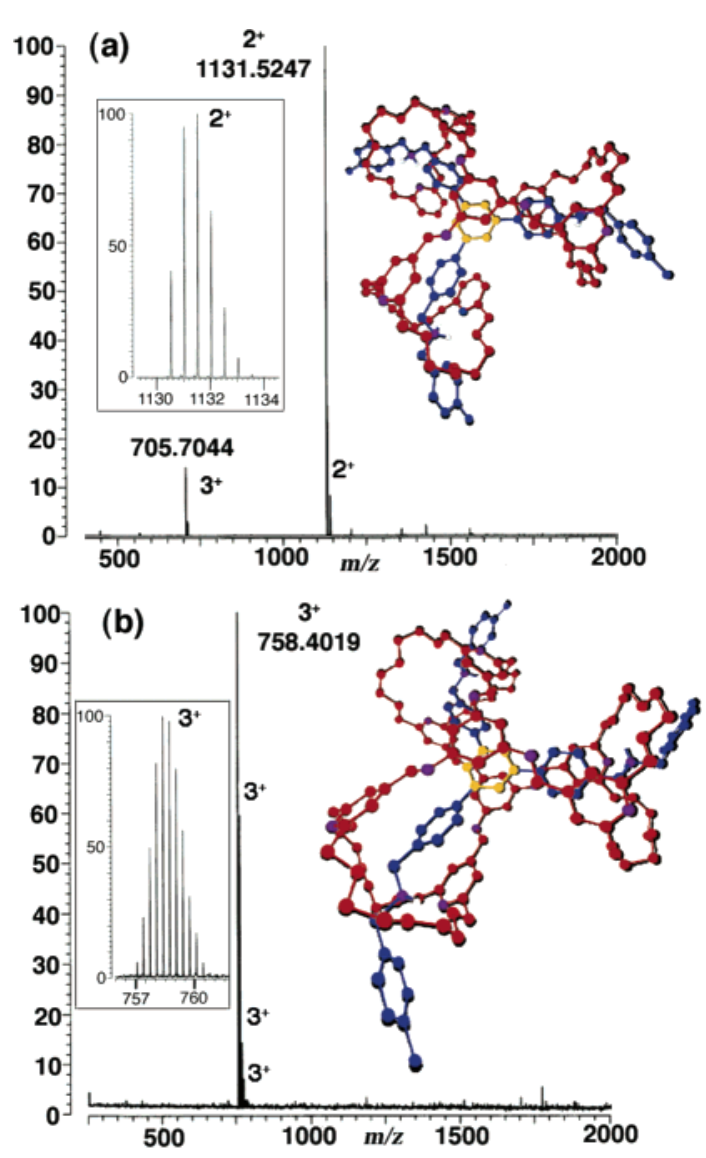

Figure 3. HR-ESI mass spectra showing the $\left[\mathrm{M}-2 \mathrm{PF}_{6}\right]^{2+}$ and $\left[\mathrm{M}-3 \mathrm{PF}_{6}\right]^{3+}$ peaks at $m / z=1131.52$ and 705.70 for (a) MFB- $\mathrm{H}_{3} \cdot 3 \mathrm{PF}_{6}$ as well as the $\left[\mathrm{M}-3 \mathrm{PF}_{6}\right]^{3+}$ peak at $\mathrm{m} / z=758.40$ for (b) $\mathbf{D F B}-\mathrm{H}_{3} \cdot 3 \mathrm{PF}_{6}$ along with the computed lowest-energy structures displayed alongside and the isotopic patterns inset within each spectra.

three $(\mathrm{CHO})_{2}$-DP24C8 macrocycles in such a way that each equivalent of TAB reacts with the three formyl groups positioned on either side of TAT- $\mathrm{H}_{3}{ }^{3+}$. Double capping of DFPR- $\mathrm{H}_{3}{ }^{3+}$ was achieved by adding 2.0 equiv of TAB to the reaction mixture containing the [4]pseudorotaxane. While capping of MFPR- $\mathrm{H}_{3}{ }^{3+}$ requires only $2 \mathrm{~h}$, double capping of DFPR- $\mathrm{H}_{3}{ }^{3+}$ requires a lot longer. Although ${ }^{1} \mathrm{H}$ NMR spectra (Figure 4) obtained $5 \mathrm{~h}$ after addition of TAB showed some initial sharpening of peaks corresponding to the highsymmetry $\left(D_{3 h}\right)$ product $\mathbf{D F B}-\mathrm{H}_{3}{ }^{3+}$, a peak at $\delta=9.84 \mathrm{ppm}$ for aldehydic protons could still be observed after $48 \mathrm{~h}$. In the event, it took 8 days for the mechanically interlocked molecular bundle DFB- $\mathrm{H}_{3}{ }^{3+}$ to become (Figure 4d) the dominant product in the ${ }^{1} \mathrm{H}$ NMR spectrum. Its formation

(23) The additional formyl group in $(\mathrm{CHO})_{2}$-DP24C8, compared to (CHO)-DP24C8, appears to have a disruptive effect upon its binding to the TAT $-\mathrm{H}_{3}{ }^{3+}$ trication, possibly as a result of the increased electronwithdrawing influence of the additional formyl group upon the electrondonating ability of the heteroatoms in the DP24C8 macrocycles.

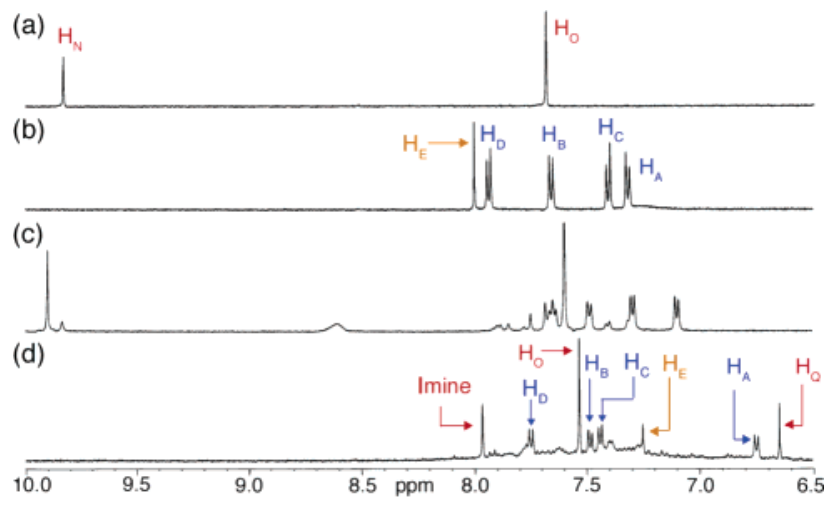

Figure 4. Partial ${ }^{1} \mathrm{H}$ NMR spectra $\left(\mathrm{CD}_{3} \mathrm{NO}_{2}, 8.8 \mathrm{mM}\right)$ of (a) $(\mathrm{CHO})_{2}-\mathbf{D P 2 4 C 8}$, (b) TAT- $\mathrm{H}_{3} \cdot 3 \mathrm{PF}_{6}$, (c) DFPR- $\mathrm{H}_{3} \cdot 3 \mathrm{PF}_{6}$, and (d) DFB- $\mathrm{H}_{3} \cdot 3 \mathrm{PF}_{6}$ and other unidentified minor products. For a definition of the proton $(\mathrm{H})$ descriptors, see Figure 1.

was confirmed (Figure 3b) by HR-ESI mass spectrometric analysis: $m / z=758.40$ for $\left[\mathrm{M}-3 \mathrm{PF}_{6}\right]^{3+}$, compared with the calculated value of 756.91 .

The mechanically interlocked molecular bundles are distinguishable $^{9}$ from regular rotaxanes. Once either the singly capped MFB- ${ }_{3}{ }^{3+}$ or doubly capped DFB- $\mathrm{H}_{3}{ }^{3+}$ has been formed, it is the mutual linking together, by a combination of supramolecular and dynamic covalent chemistry, of either five or six components, respectively, that results in the mechanically interlocking-not the addition of large stoppers to rods to constrain the movement of rings trapped thereupon. This alternative mode of construction ${ }^{24}$ of mechanically interlocked compounds represents another way of exploiting the mechanical bond at the molecular level in chemistry.

Acknowledgment. One (B.H.N.) of us thanks the ACS Division of Organic Chemistry for a graduate fellowship, sponsored by the Nelson J. Leonard ACS DOC Fellowship, sponsored by Organic Synthesis, Inc.

Supporting Information Available: Synthesis of compounds, ITC, HR-ESI, and computational modeling procedures. This material is available free of charge via the Internet at http://pubs.acs.org.

OL061262U

(24) Mechanically interlocked molecular bundles have been synthesized previously by kinetically controlled postassembly modification from triply threaded, two-component superbundles with a trifurcated trication wherein three dibenzylammonium ions are linked to a central benzenoid core. See: (a) Fyfe, M. C. T.; Lowe, J. N.; Stoddart, J. F.; Williams, D. J. Org. Lett. 2000, 2, 1221-1224. (b) Balzani, V.; Clemente-Leon, M.; Credi, A.; Lowe, J. N.; Badjić, J. D.; Stoddart, J. F.; Williams, D. J. Chem.-Eur. J. 2003, 9 , 5348-5360. (c) Badjić, J. D.; Balzani, V.; Credi, A.; Lowe, J. N.; Silvi, S.; Stoddart, J. F. Chem.-Eur. J. 2004, 10, 1926-1935. This particular synthetic approach expressed itself ultimately in the making of molecular elevators. See: (d) Badjić, J. D.; Balzani, V.; Credi, A.; Silvi, S.; Stoddart, J. F. Science 2004, 303, 1845-1849. (e) Badjić, J. D.; Ronconi, C. M.; Stoddart, J. F.; Balzani, V.; Silvi, S.; Credi, A. J. Am. Chem. Soc. 2006, $128,1489-1499$. 